\title{
Analisis Pengaruh Kepemilikan Institusional dan Profitabilitas terhadap Cash Holding dengan Ukuran Perusahaan sebagai Variabel Moderasi pada Perusahaan Terindeks LQ45 di Bursa Efek Indonesia
}

\author{
Ainul Ridha ${ }^{\left.1^{*}\right)}$, Dhian Wahyuni ${ }^{2)}$, Dewi Maya Sari ${ }^{3)}$ \\ ${ }^{1 * 2,3)}$ Program Studi Akuntansi, Sekolah Tinggi Ilmu Ekonomi Sabang, Banda Aceh \\ e-mail: aynul.ridha@gmail.com ${ }^{1 *}$
}

\begin{abstract}
:
This research is aimed to test the effect of institutional ownership and profitability on cash holding with a firm size as moderate variable in LQ45 indexed companies in Indonesia Stock Exchange from 2015 to 2017. Technique of sampling is applied with purposive sampling with 210 observations. The research is analyzed by using Moderate Regression Analysis (MRA). The results show that institutional ownership, profitability and firm size has negative effect on cash holding. The interaction test results indicate that firm size strengthen the effect of relationship between institutional ownership and cash holding and firm size strengthen the effect of relationship between profitability and cash holding.
\end{abstract}

Keyword: Cash Holding, Profitability, Instusional Ownership, Firm Size.

\section{PENDAHULUAN}

Kas adalah aset perusahaan yang paling likuid di antara aset perusahaan lainnya. Kas yang tersedia atau ditahan di perusahaan disebut dengan istilah cash holding. Menurut Gill dan Shah (2012) cash holding didefinisikan sebagai kas yang ada di perusahaan atau tersedia untuk investasi pada aset fisik dan untuk dibagikan kepada para investor. Suatu perusahaan bisa saja memiliki sejumlah besar aset fisik atau piutang, tetapi apabila kehabisan uang tunai akan mengakibatkan kebangkrutan teknis atau hilangnya peluang pertumbuhan yang berharga. Oleh karena itu, perusahaan cenderung menahan uang tunai untuk melindungi dari kekurangan kas sementara dalam melakukan pembayaran atau investasi. Kas dapat digunakan dengan segera untuk menunjang kelancaran kegiatan operasional perusahaan. Cash holding sebagai uang tunai yang diperlukan untuk memenuhi kebutuhan aktivitas operasional perusahaan sehari-hari seperti pembelian persediaan, pembayaran hutang, pembiayaan kegiatan operasional perusahaan, dan lain sebagainya.

Krisis keuangan di Amerika pada tahun 2008 berdampak ke seluruh dunia tidak terkecuali Indonesia. Umumnya krisis keuangan ini disebabkan perusahaan gagal menjaga likuiditasnya. Kejadian ini membuat perusahaan menjadi "sadar" bahwa pentingnya menjaga likuditas. Salah satu upaya untuk meminimalkan risiko likuiditas dan menjaga likuiditas adalah dengan mengelola tingkat kas serta menentukan tingkat cash holding yang optimal yang harus dimiliki oleh perusahaan. Cash holding yang optimal harus dijaga oleh perusahaan agar tidak mengalami kelebihan atau kekurangan, dan harus disediakan dalam batas jumlah yang telah ditentukan. Beberapa perusahaan di Indonesia masih tidak melakukan penyimpanan kas dalam jumlah yang besar sehingga masih banyaknya perusahaan yang memiliki masalah dalam likuiditas. Seperti pada kasus yang terjadi pada 
dua anak perusahaan Group Panghegar yakni PT. Panghegar Kana Properti dan Hotel Panghegar memiliki utang kepada PT. Bank Bukopin dan terancam pailit dikarenakan tidak dapat membayarkan hutangnya yang mencapai Rp 604M setelah perpanjangan masa pembayaran utang ditolak oleh kreditur. Contoh kasus tersebut dapat dijadikan pelajaran untuk perusahaan-perusahaan lainnya bahwa perusahaan harus tetap memperhatikan pengelolaan kas agar kepemilikan kas perusahaan tetap optimal sehingga likuiditas perusahaan tetap terjaga dengan baik

Dalam konteks pengaruhnya, Kepemilikan Institusional memiliki pengaruh terhadap cash holding. Manajer sebagai bagian dari perusahaan lebih suka mempertahankan cash holding untuk kepentingan mereka sendiri daripada meningkatkan pembayaran kepada pemegang saham ketika perusahaan memiliki peluang investasi yang buruk.

Profitabilitas juga diperkirakan mempengaruhi cash holding, hal ini didasarkan hasil penelitian Mohd, Latif dan Saleh (2015), Sari dan Ardian (2019) yang menemukan pengaruh positif profitabilitas terhadap cash holding.Jika dikaitkan dengan Teori Pecking Order, peningkatan profitabilitas akan menyebabkan cash holding meningkat karena perusahaan akan menggunakan profitabilitasnya untuk meningkatkan likuiditas. Oleh karena itu, perusahaan cenderung untuk memiliki lebih banyak cash holding (Opler, Pinkowitz, Stulz, dan Williamson, 1999).

Ukuran Perusahaan dapat memoderasi hubungan antara kepemilikan institusional dan profitabilitas dengan cash holding karena menurut Kim, Kim, dan Woods (2011) perusahaan besar memiliki akses yang mudah dan murah untuk masuk ke pasar modal dibandingkan perusahaan kecil. Perusahaan besar tidak perlu mengumpulkan kas dalam jumlah yang besar seperti yang dilakukan oleh perusahaan kecil untuk menghindari peluang investasi yang tidak bisa diambil karena keterbatasan pendanaan.

Penelitian pengaruh kepemilikan institusional terhadap cash holding telah pernah diteliti oleh Azinfar dan Shiraseb (2016) dengan hasil penelitian menunjukkan bahwa kepemilikan institusional mempengaruhicash holding. Hasil penelitian Khan, Bibi, dan Tanveer (2016) dan Im, Park, Pathan, dan Yu (2018) lebih spesifik menunjukkan arah pengaruh antara kepemilikan institusional dan cash holding yaitu berpengaruh positif. Hasil berbeda ditemukan oleh Mawardi dan Nurhalis (2018) dimana hasil penelitiannya menunjukkan bahwa kepemilikan institusional berpengaruh negatif terhadap cash holding. Hasil penelitian lainnya yaitu Senjaya dan Yadnyana (2016) menemukan bahwa kepemilikan institusional tidak berpengaruh terhadap cash holding.

Hasil penelitian Mohd et al. (2015), Ali, Ullah, dan Ullah (2016), Cheryta, Moeljadi, dan Indrawati (2017), Arfan et al. (2017) serta Sari dan (Ardian 2019) menemukan bahwa profitabilitas berpengaruh positif terhadap cash holding. Pada penelitian lainnya yang dilakukan oleh Silaen dan Prasetiono (2017) menunjukkan bahwa profitabilitas tidak berpengaruh terhadap cash holding.

Penelitian terdahulu pada umumnya sebagian besar peneliti mempertimbangkan negara-negara maju untuk studi mereka sementara sedikit literatur tersedia untuk faktor-faktor penentu cash holding di sektor LQ45di Indonesia sehingga perbedaan ini akan menjadi kesenjangan penelitian. Perbedaan 
hasil penelitian pada peneliti sebelumnya juga menjadi fenomena menarik untuk dianalisis terutama dikarenakan perbedaan karakteristik dan variabel yang mempengaruhi cash holding di negara maju maupun di negara berkembang seperti di Indonesia.

Penelitian ini memberikan kontribusi berupa bukti empiris mengenai faktor-faktor yang berpengaruh terhadap cash holding perusahaan. Penelitian ini dapat dijadikan bahan pertimbangan bagi perusahaan untuk membuat keputusan berkaitan dengan penentuan tingkat cash holding perusahaan. Tujuan dari penelitian ini adalah untuk menyelidiki peran moderasi ukuran perusahaan terhadap hubungan antara kepemilikan institusional, profitabilitas dan cash holding di perusahaan terindeks LQ45 tahun 2015-2017. Arti penting dari penelitian ini adalah untuk menekankan relevansi ukuran perusahaan sebagai penjelasan yang mungkin dari interaksi dalam memperkuat dan melemahkan pengaruh kepemilikan institusional dan profitabilitas terhadap cash holding perusahaan terindeks LQ45 di Bursa Efek Indonesia.

\section{TINJAUAN PUSTAKA}

\section{Cash Holding}

Manfaat cash holding berasal dari dua motif. Menurut motif biaya transaksi, keuntungan utama cash holding adalah bahwa perusahaan menghemat biaya transaksi untuk mengumpulkan dana dan tidak harus melikuidasi aset untuk melakukan pembayaran. Akibatnya, perusahaan akan memegang lebih banyak kas ketika kemungkinan akan dikenakan biaya transaksi yang lebih tinggi untuk mengubah aset non-kas menjadi kas (Guzani, 2017).

Teori-teori yang menentukan perilaku perusahaan dalam cash holding adalah Trade-off Theory, Pecking Order Theory, Free Cash Flow Theory (Wasiuzzaman, 2014). Menurut Trade off Theory, perusahaan mempertahankan tingkat kas optimal pada titik impas di mana biaya marjinal dan manfaat memegang uang tunai adalah sama (Al-Najjar, 2011; Martínez, Teruel, dan Solano, 2011). Didasarkan pada Pecking Order Theory, perusahaan lebih memilih pembiayaan internal untuk membiayai rencana investasi mereka dengan memanfaatkan aset likuid dan laba ditahan. Setelah itu, utang dikeluarkan sementara, penerbitan ekuitas dianggap sebagai pilihan terakhir.

Di satu sisi, Pecking Order Theory mendukung bahwa perusahaan dengan laba tinggi sebagian besar akan membiayai rencana investasi dengan sumber daya internal sehingga perusahaan-perusahaan ini cenderung memiliki rasio kas yang tinggi. Argumen ini didukung lebih lanjut oleh Afza dan Adnan (2007); Uyar dan Kuzey (2014) dan Wasiuzzaman (2014), Trade off Theory mengungkapkan hubungan terbalik antara perilaku cash holding dan arus kas perusahaan (Gill dan Mathur, 2011; Kim, Kim dan Woods, 2011). Ini menunjukkan bahwa perusahaan yang memiliki arus kas tinggi memberikan prioritas pada dana eksternal untuk peluang investasi mereka dan memperoleh melindungi pajak.

Cash holding bisa diukur menggunakan formula berikut ini (Ogundipe dan Anjao, 2012): 
Cash Holding $=\frac{\text { Kas dan setara kas }}{\text { Total Aset }}$

\section{Kepemilikan Institusional}

Kepemilikan institusional merupakan proporsi kepemilikan saham yang dimiliki oleh pemilik institusi dan blockholders pada akhir tahun. Yang dimaksud institusi adalah perusahaan investasi, bank, perusahaan asuransi, maupun lembaga lain yang bentuknya seperti perusahaan, sedangkan yang dimaksud blockholders adalah kepemilikan individu atas nama perorangan diatas 5\% yang tidak termasuk dalam kepemilikan manajerial (Wahyudi dan Pawestri, 2016).

Kepemilikan institusional memiliki arti penting dalam memonitor manajemen karena dengan adanya kepemilikan oleh institusional akan mendorong peningkatan pengawasan yang lebih optimal. Monitoring tersebut tentunya akan menjamin kemakmuran untuk pemegang saham, pengaruh kepemilikan institusional sebagai agen pengawas ditekan melalui investasi mereka yang cukup besar dalam pasar modal.

Kepemilikan institusional diukur dengan menggunakan indikator jumlah presentase kepemilikan saham yang dimiliki oleh pihak institusi dari seluruh jumlah modal saham yang beredar (Sukirni, 2012). Wening (2009) menyatakan bahwa pengukuran kepemilikan institusional mengacu pada:

Kepemilikan Institusional $=\frac{\text { Jumlah saham yang dimiliki institusional }}{\text { Jumlah saham beredar }}$

\section{Profitabilitas}

Perusahaan yang kurang menguntungkan atau yang memiliki tingkat profitabilitas rendah akan terus mengurangi uang tunai dan menggunakan utang sebagai sumber pendanaan mereka. Perusahaanperusahaan ini akan enggan mengeluarkan ekuitas, karena tingginya biaya penerbitan (Dittmar et al., 2003).

Profitabilitas dalam penelitian ini diproksikan dengan menggunakan return on assets (ROA). Dimana ROA menunjukkan ukuran kemampuan perusahaan secara keseluruhan menghasilkan keuntungan dengan jumlah keseluruhan aktiva yang ada dalam perusahaan. Profitabilitas dalam penelitian ini diproksikan dengan ROA karena rasio ini memberikan ukuran lebih baik atas profitabilitas perusahaan serta menunjukkan efektivitas perusahaan dalam memperoleh keuntungan. Harahar (2009) menyatakan bahwa ROA dihitung menggunakan rumus sebagai berikut:

$$
\mathrm{ROA}=\frac{\text { Laba Bersih }}{\text { Total Aset }}
$$

\section{Ukuran Perusahaan}

Ukuran perusahaan adalah ukuran dari nilai ekuitas, total penjualan, atau total nilai aset yang dimiliki oleh perusahaan (Souissi dan Khlif, 2012). semakin besar ukuran perusahaan, semakin besar kemungkinan terjadinya masalah keagenan. Cara untuk meminimalkan masalah keagenan adalah 
dengan meminimalkan cash holding (Cheryta et al., 2017).

Ukuran perusahaan diproksikan dengan log natural total aset, tujuannya agar mengurangi perbedaan yang signifikan antara ukuran perusahaan besar dan ukuran perusahaan kecil sehingga data total aset dapat terdistribusi normal (Sari dan Ardian, 2012). Pengukuran ukuran perusahaan dilakukan dengan menggunakan rumus sebagai berikut:

Size $=\log ($ Total Aktiva $)$

\section{Kerangka Pemikiran}

\section{Pengaruh Kepemilikan Institusional terhadap Cash Holding}

Transparansi dan kepemilikan institusional saling berhubungan positif dimana ketika kepemilikan institusional tinggimaka transparansi juga tinggi disebabkan keberadaan institusi sebagai pemilik saham menuntut perusahaan untuk memberikan informasi yang lebih terbuka, karena investor institusi biasanya lebih proaktif dalam pengawasanInvestasinya.Hasil penelitian (Im et al., 2018) menemukan bahwa perusahaan yang memiliki kepemilikan institusional yang tinggi juga memiliki cash holding tinggi pula.

Cash holding merupakan item yang paling likuid untuk disalahgunakan dengan mudah. Adanya konflik kepentingan antara tugas/tujuan utama manajemen yaitu meningkatkan kesejahteraan Institusional dengan kepentingan manajemen untuk meningkatkan kesejahteraan mereka sendiri bisa diminimalisir. Pemegang saham institusional memiliki peran mengendalikan. Hal ini berarti bahwa mereka bisa mengendalikan dan mengawasi manajer dalam waktu jangka panjang sehingga perusahaan tidak akan rusak (Azinfar dan Shiraseb, 2016). Selain itu kepemilikan institusional juga dapat mengurangi masalah keagenan antara pihak principal dengan pihak manajemen perusahaan (Mawardi dan Nurhalis, 2018).

$\mathrm{H}_{1}$ : Kepemilikan Institusional berpengaruh terhadap Cash Holding

\section{Pengaruh Profitabilitas terhadap Cash Holding}

Profitabilitas merupakan kemampuan perusahaan menghasilkan laba dalam periode tertentu.Rasio profitabilitas adalah indikator yang sangat penting bagi investor, untuk mengukur kemampuan perusahaan untuk mendapatkan laba bersih terkait dengan dividen. Dengan demikian, peningkatan profitabilitas di perusahaan dapat diartikan untuk meningkatkan laba bersih perusahaan yang bersangkutan. Peningkatan laba bersih dapat menjadi salah satu indikasi bahwa perusahaan dapat menandai operasinya dengan menggunakan dana internal, sehingga perusahaan akan menghemat uang tunai dengan jumlah yang lebih besar (Cheryta et al., 2017).

Selain itu, profitabilitas yang tinggi menunjukkan kemampuan perusahaan dalam menghasilkan keuntungan yang tinggi bagi perusahaannya. Keuntungan akan menjadi laba ditahan yang digunakan sebagai penyangga bagi perusahaan dan dapat menambah cash holding. Hal ini sesuai dengan pecking order theory yang menyatakan bahwa perusahaan lebih memilih menggunakan laba 
ditahan sebagai tambahan modal dibandingkan mendapatkannya melalui penerbitan ekuitas yang tergolong mahal. Perusahaan yang kurang menguntungkan atau yang memiliki tingkat profitabilitas rendah akan terus mengurangi uang tunai dan menggunakan utang sebagai sumber pendanaan mereka (Cheryta et al., 2017).

Penelitian yang dilakukan Ogundipe et.al, (2012), Mohd et al., (2015), Ali et al. (2016), Cheryta et al. (2017), Arfan et al. (2017) dan Sari dan Ardian (2019) menemukan bahwa terdapat hubungan yang positif antara profitabilitas dengan cash holding.

$\mathrm{H}_{2}$ : Profitabilitas berpengaruh terhadap Cash Holding

\section{Pengaruh Ukuran Perusahaan terhadap Nilai perusahaan}

Perusahaan besar dianggap memiliki diversifikasi dari pada perusahaan kecil dan pada gilirannya kurang rentan terhadap biaya kebangkrutan sehingga lebihkecil kemungkinannya untuk persediaan cash holding (Al-Najjar dan Belghitar, 2011). Namun, jika ukuran perusahaan dipandang sebagai indeks untuk financial distress, maka perusahaan skala kecil lebih mungkin untuk dilikuidasi jika menderita financial distress. Oleh karena itu perusahaan skala kecil diharapkan relatif untuk memiliki cash holding lebih untuk menghindari financial distress. Disisi lain, pecking order theory memprediksikan hubungan antara ukuran perusahaan dan cash holding adalah positif dikarenakan perusahaan besar secara tipikal memiliki performa lebih baik dari pada perusahaan kecil dan seharusnya memiliki cash holding lebih besar (Opler et al., 1999). Pernyataan ini didukung oleh (Kafayat, Rehmanm dan Farooq, 2014) menunjukkan bahwa perusahaan yang lebih besar memiliki lebih banyak uang tunai dan hasil ini mendukung pecking order theory tentang pembiayaan investasi. $\mathrm{H}_{3}$ : Ukuran Perusahaan berpengaruh terhadap Cash Holding.

\section{Pengaruh Ukuran Perusahaan terhadap Hubungan antara Kepemilikan Institusional terhadap Cash Holding}

Investor institusi dapat dianggap sebagai salah satu kontrol eksternal karena sebagai pemantau dimana tujuan mereka adalah memaksimalkan nilai (Im, Park, Pathan dan Yu, 2018). Ketika perusahaan berukuran besar, kepemilikan institusional tentu semakin besar pula yang menandakan akan semakin besar kekuatan suara dan dorongan dari institusi tersebut untuk mengawasi manajemen. Akibatnya, akan memberikan dorongan yang lebih besar untuk mengoptimalkan cash holding perusahaan.

Ukuran perusahaan yang besar tentunya akan menarik investor institusional untuk berinvestasi. Investor institusional memiliki kekuatan untuk menetapkan pengaruh yang cukup besar pada pelaksanaan kegiatan operasional perusahaan (Brigham dan Houston, 2011). Investor institusional mempunyai saham yang cukup untuk mempengaruhi manajemen perusahaan (Griffin dan Ebert dalam Molan, 2011). Sebelum menanamkan modalnya dalam suatu perusahaan, investor institusional biasanya akan memberikan perhatian yang lebih terhadap kinerja perusahaan. Hal ini 
dilakukan mengingat dividen atas investasi sangat tergantung pada bagaimana kinerja perusahaan dan bagaimana pengoptimalan cash holding perusahaan dilakukan.

$\mathrm{H}_{4}$ : Ukuran Perusahaan berpengaruh terhadap hubungan antara kepemilikan institusional dengan Cash Holding

\section{Pengaruh Ukuran Perusahaan terhadap Hubungan antara Profitabilitas terhadap Cash Holding}

Perusahaan besar memiliki proporsi biaya kebangkrutan yang relatif kecil terhadap nilai total perusahaan dan biaya financial distress yang rendah serta memiliki nilai jaminan yang besar. Perusahaan yang berukuran besar dapat dicerminkan oleh jumlah aset yang besar. ukuran aset suatu perusahaan dapat menjadi salah satu tolok ukur yang menunjukkan besar kecilnya perusahaan tersebut (Sofyaningsih dan Hardiningsih, 2011). Perusahaan kecil cenderung memiliki jumlah kepemilikan kas yang lebih tinggi untuk menghindari kekurangan uang tunai (Alves dan Morais, 2018). Jamil, Anwar, Afzaal, Tariq dan Asif (2016) menjelaskan bahwa tingkat kas meningkat secara signifikan sesuai ukuran perusahaannya.

Semakin besar aset yang dimiliki, perusahaan memiliki dana yang besar untuk menunjang kelancaran aktivitas bisnis melalui investasi baik pada aset tetap maupun aset lancar perusahaan. Oleh karena itu, ukuran perusahaan yang semakin besar diharapkan akan memberikan kesempatan perusahaan dalam memperoleh laba yang besar pula, sehingga akan berdampak meningkatnya return perusahaan maupun investor. Apabila profitabilitas besar mengindikasikan jumlah kepemilikan kas yang cukup, serta perusahaan bisa menyediakan cash holding dalam jumlah yang optimal.Perusahaan yang lebih besar seharusnya memiliki akses yang lebih besar ke sumber pembiayaan eksternal dan diharapkan dapat memperoleh dana tersebut dengan biaya yang lebih murah.Secara teori perusahaan yang lebih besar cenderung memiliki lebih sedikit uang tunai (Zoubi, 2013)

$\mathrm{H}_{5}$ : Ukuran Perusahaan berpengaruh terhadap hubungan antara profitabilitas dengan Cash Holding

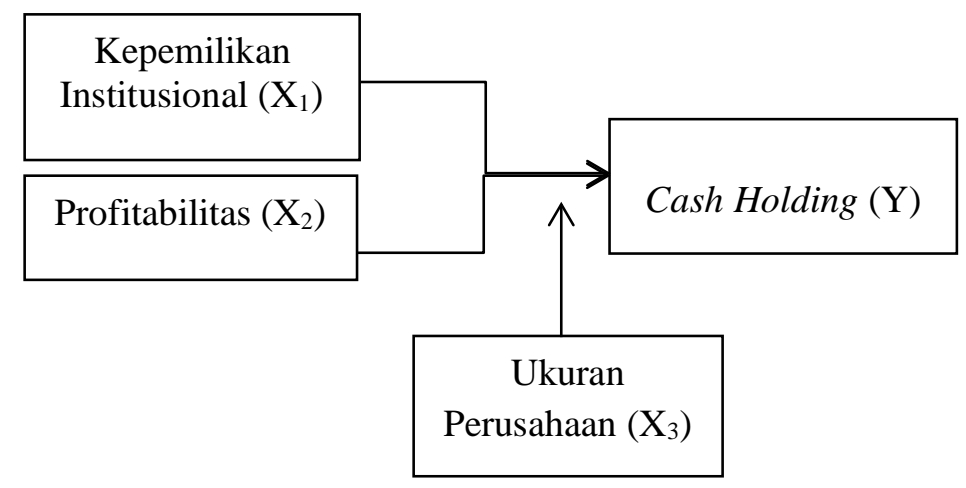

Gambar 2. Kerangka Pemikiran 


\section{METODE PENELITIAN}

Teknik pengambilan sampel dilakukan secara purposive sampling dengan tujuan untuk mendapatkan sampel yang sesuai dengan kriteria yang telah ditentukan. Sesuai dengan kriteria tersebut didapati sampel sebanyak 210 pengamatan.

\section{Variabel Independen}

1. Kepemilikan Institusional $\left(\mathrm{X}_{1}\right)$

Kepemilikan institusional diukur dengan menggunakan indikator jumlah presentase kepemilikan saham yang dimiliki oleh pihak institusi dari seluruh jumlah modal saham yang beredar (Sukirni, 2012). Wening (2009) menyatakan bahwa pengukuran kepemilikan institusional mengacu pada:

Jumlah saham yang dimiliki institusional $=\frac{\text { Kepemilikan Institusional }}{\text { Jumlah saham yang beredar }}$

\section{Profitabilitas $\left(\mathrm{X}_{2}\right)$}

Perusahaan yang kurang menguntungkan atau yang memiliki tingkat profitabilitas rendah akan terus mengurangi uang tunai dan menggunakan utang sebagai sumber pendanaan mereka. Perusahaan-perusahaan ini akan enggan mengeluarkan ekuitas, karena tingginya biaya penerbitan (Dittmar et al., 2003). Harahap (2009) menyatakan bahwa ROA dihitung menggunakan rumus sebagai berikut:

$$
\mathrm{ROA}=\frac{\text { Laba Bersih }}{\text { Total Aset }}
$$

\section{Variabel Dependen}

Pada Penelitian ini, variavel dependen adalah cash holding. Manfaat cash holding berasal dari dua motif. Menurut motif biaya transaksi, keuntungan utama cash holdingadalah bahwa perusahaan menghemat biaya transaksi untuk mengumpulkan dana dan tidak harus melikuidasi aset untuk melakukan pembayaran. Akibatnya, perusahaan akan memegang lebih banyak kas ketika kemungkinan akan dikenakan biaya transaksi yang lebih tinggi untuk mengubah aset non-kas menjadi kas (Guzani, 2017).

Ogundipe, Ogundipe, dan Anjao (2012) menyatakan bahwa Cash holding bisa diukur menggunakan formula berikut ini:

Cash Holding $=\frac{\text { Kas dan setara kas }}{\text { Total Aset }}$

\section{Variabel Pemoderasi}

Dalam penelitian ini, variabel pemoderasi adalah Ukuran perusahaan $\left(\mathrm{X}_{3}\right)$.Ukuran perusahaan adalah ukuran dari nilai ekuitas, total penjualan, atau total nilai aset yang dimiliki oleh perusahaan (Souissi dan Khlif, 2012). Semakin besar ukuran perusahaan, semakin besar kemungkinan terjadinya 
masalah keagenan. Cara untuk meminimalkan masalah keagenan adalah dengan meminimalkan cash holding (Cheryta, Moeljadi, Indrawati, 2017).

Size $=\log ($ Total Aktiva $)$

\section{Rancangan Pengujian Hipotesis}

Data penelitian dianalisis dengan menggunakan metode analisis regresi interaksi atau Moderate Regression Analysis (MRA). Analisis regresi interaksi bertujuan untuk mengetahui apakah variabel moderating akan memperkuat atau memperlemah hubungan antara variabel independen dan variabel dependen. Data diolah dengan menggunakan SPSS. Adapun regresi iteraksinya sebagai berikut:

$$
\mathrm{CH}=\alpha+\beta_{1} \mathrm{KI}+\beta_{2} \mathrm{P}+\beta_{3} \mathrm{UP}+\beta_{4} \mathrm{KI} * \mathrm{UP}+\beta_{5} \mathrm{P} * \mathrm{UP}+\varepsilon
$$

Keterangan:

$\begin{array}{ll}\mathrm{CH} & =\text { Cash Holding } \\ \alpha & =\text { Konstanta } \\ \beta_{1,2,3,4} & =\text { Koefisien regresi } \\ \mathrm{KI} & =\text { Kepemilikan Institusional } \\ \mathrm{P} & =\text { Profitabilitas } \\ \mathrm{UP} & =\text { Ukuran Perusahaan } \\ \varepsilon & =\text { error term }\end{array}$

Pengujian asumsi klasik juga dilakukan pada penelitian ini bertujuan untuk mengetahui apakah model regresi tersebut merupakan model regresi yang baik atau tidak (Ghozali, 2006). Uji asumsi klasik yang digunakan yaitu uji multikolonieritas, uji heteroskedastisitas, uji normalitas, dan uji autokorelasi.

Pengujian hipotesis pertama bertujuan untuk mengetahui apakah kepemilikan institusional, profitabilitas dan ukuran perusahaan secara bersama-sama berpengaruh terhadap cash holding. Pengujian hipotesis kedua bertujuan untuk mengetahui apakah kepemilikan institusional berpengaruh terhadap cash holding. Pengujian hipotesis ketiga bertujuan untuk mengetahui apakah profitabilitas berpengaruh terhadap cash holding. Pengujian hipotesis keempat bertujuan untuk mengetahui apakah ukuran perusahaan berpengaruh terhadap cash holding. Pengujian hipotesis kelima bertujuan untuk mengetahui apakah ukuran perusahaanmempengaruhi hubungan antara kepemilikan institusional dengancash holding. Pengujian hipotesis keenam bertujuan untuk mengetahui apakah ukuran perusahaan berpengaruh terhadap hubungan antara profitabilitas dengancash holding.

Kriteria pengujian hipotesis adalah sebagai berikut:

$H_{01}: \beta_{1}=\beta_{2}=\beta_{3}=0$; Variabel independen tidakberpengaruh terhadap variabel dependen. Ha: Minimal satu $\beta \mathrm{i} \quad(\mathrm{i}=1,2,3) \neq 0$; Variabel independen berpengaruh terhadap variabel dependen. 


\section{HASIL DAN PEMBAHASAN}

\section{Hasil Pengujian Asumsi Klasik}

\section{Hasil Uji Multikolonieritas}

Berdasarkan hasil uji multikolonieritas, diketahui bahwa tidak ada variabel independen yang memiliki nilai tolerance kurang dari 0,10 dan nilai VIF lebih besar dari 10. Hal ini berarti bahwa ketiga variabel independen tersebut tidak terjadi multikolinieritas.

\section{Hasil Uji Heteroskedastisitas}

Uji heteroskedastisitas bertujuan menguji apakah dalam model regresi terjadi ketidaksamaan variancedari residual satu pengamatan ke pengamatan yang lain. Jika variance dari residual satu pengamatan lain tetap, maka disebut homoksedastisitas dan jika berbeda disebut heteroskedasitisitas.

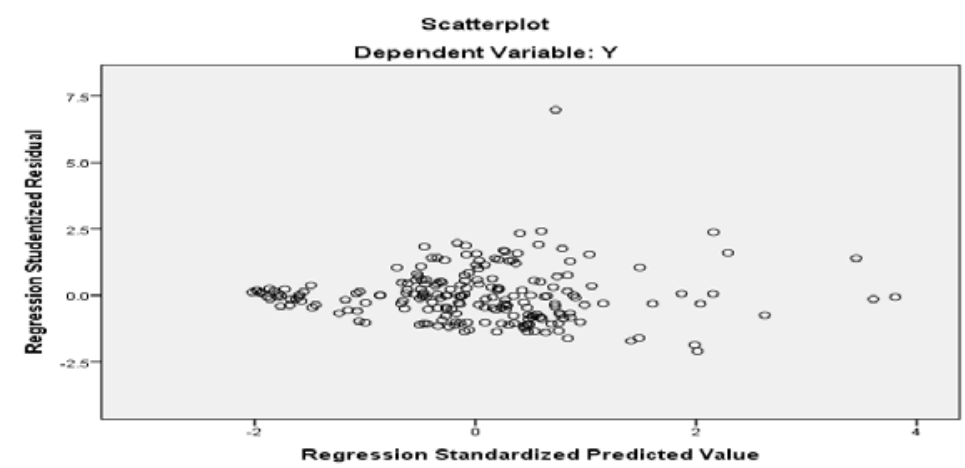

Gambar 1. Grafik Scatterplot Uji Heteroskedastisitas Sumber: Data Diolah (2019)

Berdasarkan hasil uji heteroskedastisitas pada Gambar 1, diketahui bahwa tidak ada pola yang jelas, serta titik-titik menyebar di atas dan di bawah angka 0 pada sumbu Y, maka tidak terjadi heteroskedastisitas.

\section{Uji Normalitas}

Berdasarkan hasil uji normalitas diketahui data menyebar disekitar garis diagonal dan mengikuti arah garis diagonal atau grafik histogramnya menunjukkan pola distribusi normal, maka model regresi memenuhi asumsi normalitas. Hasil uji ini dapat dilihat pada Gambar 2.

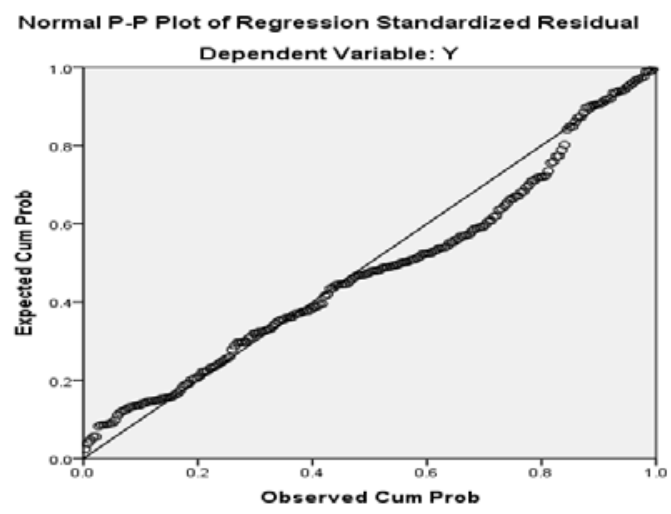

Gambar 2. Grafik Uji Normalitas

Sumber: Data Diolah (2019) 


\section{Hasil Uji Autokorelasi}

Berdasarkan hasil uji autokorelasi diketahui nilai DW 1,269 lebih besar dari batas atas (dU) 1,269 dan kurang dari 4-1,269 (4 - dU). Dengan demikian, dapat disimpulkan bahwa model regresi terbebas dari autokorelasi.

Tabel 1 Hasil Uji Autokorelasi

\begin{tabular}{|c|c|c|c|c|c|c|c|c|c|c|}
\hline \multirow[b]{2}{*}{ Model } & \multirow[b]{2}{*}{$\mathrm{R}$} & \multirow[b]{2}{*}{$\begin{array}{c}\mathrm{R} \\
\text { Square }\end{array}$} & \multirow{2}{*}{$\begin{array}{c}\text { Adjuste } \\
\text { d R } \\
\text { Square }\end{array}$} & \multirow{2}{*}{$\begin{array}{l}\text { Std. } \\
\text { Error of } \\
\text { the } \\
\text { Estimate }\end{array}$} & \multicolumn{5}{|c|}{ Change Statistics } & \multirow[b]{2}{*}{$\begin{array}{l}\text { Durbin- } \\
\text { Watson } \\
\end{array}$} \\
\hline & & & & & $\begin{array}{l}\text { R Square } \\
\text { Change }\end{array}$ & $\begin{array}{c}\mathrm{F} \\
\text { Change }\end{array}$ & df1 & df2 & $\begin{array}{c}\text { Sig. F } \\
\text { Change }\end{array}$ & \\
\hline 1 & $.321^{\mathrm{a}}$ & .103 & .090 & .087917 & .103 & 7.870 & 3 & 206 & .000 & 1.269 \\
\hline
\end{tabular}

a. Predictors: (Constant), X3, X1, X2

b. Dependent Variable: Y

Sumber: Data Diolah (2019)

\section{Hasil Pengujian Hipotesis}

Hasil regresi pengaruh kepemilikan institusional dan profitabilitas terhadap cash holding perusahaan dapat dilihat pada Tabel 2.

Tabel 2. Hasil Regresi Pengaruh Kepemilikan Institusional dan Profitabilitas terhadap Cash Holding dengan Ukuran Perusahaan sebagai Variabel Moderasi

\begin{tabular}{cccccc}
\hline Model & B & Std. Error & Beta & $\mathrm{t}$ & Sig. \\
\hline (Constant) & 1.471 & .770 & & 1.910 & .058 \\
X1 & -1.440 & 1.263 & -2.893 & -1.140 & .256 \\
X2 & -1.710 & 2.551 & -1.410 & -.670 & .503 \\
X3 & -.098 & .057 & -.646 & -1.723 & .086 \\
X1X3 & .105 & .094 & 2.846 & 1.119 & .264 \\
X2X3 & .143 & .196 & 1.517 & .731 & .465 \\
\hline R & $:$ & $.329^{a}$ & & & \\
R Square & $:$ & .108 & & & \\
Adjusted R Square & $:$ & .087 & & \\
Std. Error of the Estimate & $:$ & .088071 & &
\end{tabular}

Sumber: Data Diolah (2019)

Berdasarkan Tabel 2, dapat dilihat bahwa nilai konstanta sebesar 1,471. Nilai konstanta ini menunjukkan bahwa jika kepemilikan institusional, profitabilitas dan ukuran perusahaan dianggap konstan, maka besarnya cash holding perusahaan akan turun sebesar 147,1\%. Koefisien regresi kepemilikan Institusional sebesar -1.440 berarti bahwa setiap kenaikan 100\% dari kepemilikan Institusional akan menurunkan cash holding sebesar 144\% dengan asumsi variabel independen lainnya konstan. Koefisien regresi profitabilitas sebesar -1.710 berarti bahwa setiap kenaikan $100 \%$ dari profitabilitas akan menurunkan cash holding sebesar 171\% dengan asumsi variabel independen lainnya konstan. Koefisien regresi ukuran perusahaan sebesar -.098 berarti bahwa setiap kenaikan 100\% dari ukuran perusahaan akan menurunkan cash holding sebesar 98\% dengan asumsi variabel independen lainnya konstan. 
Hipotesis pertama terjawab dalam hasil pengujian hipotesis secara bersama-sama, sedangkan hipotesis kedua, ketiga, keempat, kelima, dan keenam terjawab dalam hasil pengujian secara parsial. Hasil regresi interaksi atau Moderate Regression Analysis (MRA) sebagai berikut:

$$
\mathrm{CH}=1,471-1.440 \mathrm{KI}-1,710 \mathrm{P}-0,98 \mathrm{UP}-0,105 \mathrm{KI} * \mathrm{UP}+0.143 \mathrm{P} * \mathrm{UP}+\varepsilon .
$$

\section{Pengaruh Kepemilikan Institusional, Profitabilitas dan Ukuran Perusahaan secara bersama- sama terhadap Cash Holding}

Nilai koefisien regresi masing-masing variabel independen adalah $-1,440,-1,710,-0,98$. Nilai ini menunjukkan bahwa kepemilikan institusional, profitabilitas dan ukuran perusahaan tidak sama dengan nol $\left(\beta_{1} \neq 0 ; \beta_{\mathrm{i}}=1,2,3\right)$. Dengan demikian dapat dikatakan bahwa hipotesis pertama yaitu kepemilikan institusional, profitabilitas dan ukuran perusahaan berpengaruh terhadap cash holding dapat diterima.

Untuk menguji pengaruh secara simultan dapat juga dilakukan dengan menggunakan uji koefisien determinasi $\left(\mathrm{R}^{2}\right)$. Apabila $\mathrm{R}^{2} \neq 0$ maka kepemilikan institusional, profitabilitasdan ukuran perusahaan berpengaruh terhadap cash holding. Berdasarkan Tabel 1, nilai menunjukkan 0,108 atau 10,8\%, maka hal ini menunjukkan bahwa kepemilikan institusional, profitabilitas dan ukuran perusahaan secara bersama-sama (simultan) berpengaruh terhadap cash holding. Nilai ini menunjukkan bahwa cash holding dipengaruhi oleh kepemilikan institusional, profitabilitas dan ukuran perusahaan sebesar 10,8\%, sementara 89,2\% sisanya dipengaruhi oleh variabel lain yang tidak dimasukkan dalam penelitian ini.

\section{Pengaruh Kepemilikan Institusional terhadap Cash Holding}

Hasil pengujian hipotesis menunjukkan bahwa kepemilikan Institusionalberpengaruh signifikan terhadap cash holding dengan nilai koefisien regresi sebesar -1,440. Kepemilikan institusional akan menurunkan cash holding dikarenakan ketika terjadi peningkatan kepemilikan saham oleh institusional, maka akan lebih banyak pihak eksternal perusahaan yang juga sebagai pemilik perusahaan akan mengawasi keberlangsungan hidup perusahaan serta segala kegiatannya. Dengan adanya pengawasan yang ketat maka seluruh informasi yang diberikan oleh manajemen harus terbuka atau transparankepada stakeholders. Dengan transparansi inisecaraotomatis akan membuat manajemen menghindari tindakan-tindakan yang akan merugikan perusahaan. Kesimpulannya, ketika terjadi peningkatan kepemilikan institusional maka cash holdings akan menurun.

Hasil penelitian ini sejalan dengan hasil penelitian (Mawardi dan Nurhalis, 2018) yang menemukan bahwa kepemilikan institusional berpengaruh negatif terhadap cash holding. Namun hasil penelitian ini berbeda dengan penelitian yang telah dilakukan oleh (Khan et al., 2016) dan (Im et al., 2018) yang menemukan bahwa kepemilikan institusional berpengaruh positif terhadap cash holding serta hasil penelitian lainnya (Senjaya \& Yadnyana, 2016)dan (Yanti, Susanto, Wirianata, \& Viriany, 2019) menemukan bahwa kepemilikan institusional tidak berpengaruh terhadap cash holding. 


\section{Pengaruh Profitabilitas berpengaruh terhadap Cash Holding}

Hasil pengujian hipotesis menunjukkan bahwa Profitabilitas berpengaruh negatif terhadap Cash Holding dengan nilai koefisien regresi sebesar -1,710. Pengaruh negatif ini menunjukkan bahwa semakin besar profitabilitas maka semakin kecil cash holding perusahaan.

Hal ini menunjukkan bahwa peningkatan Profitabilitas akan berpengaruh terhadap Cash Holding. Profitabilitas yang tinggi menunjukkan kemampuan perusahaan menghasilkan keuntungan yang tinggi. Keuntungan akan menjadi laba ditahan yang digunakan sebagai penyangga bagi bank dan dapat menambah cash holding. Hal ini sesuai dengan pecking order theory yang menyatakan bahwa perusahaan lebih memilih menggunakan laba ditahan sebagai tambahan modal dibandingkan mendapatkannya melalui penerbitan ekuitas yang tergolong mahal.Peningkatan profitabilitas di perusahaan dapat diartikan untuk meningkatkan laba bersih perusahaan yang bersangkutan. Peningkatan laba bersih dapat menjadi salah satu indikasi bahwa perusahaan dapat menandai operasinya dengan menggunakan dana internal, sehingga perusahaan akan menghemat uang tunai dengan jumlah yang lebih besar (Cheryta et al., 2017).

Hasil penelitian ini berbeda dengan hasil penelitian sebelumnya yang dilakukan oleh (Zoubi, 2013), (Mohd et al., 2015), (Ali et al., 2016), (Cheryta et al., 2017), (Arfan et al., 2017) dan (Sari dan Ardian, 2019) yang menemukan bahwa profitabilitas berpengaruh positif terhadap cash holding. Hasil berbeda juga di dapatkan oleh (Silaen dan Prasetiono, 2017) yang menemukan tidak ada pengaruh antara profitabilitas dan cash holding.

\section{Ukuran Perusahaan berpengaruh terhadap Cash Holding}

Hasil pengujian hipotesis menunjukkan bahwa Ukuran Perusahaan berpengaruh negatif terhadap Cash Holding dengan nilai koefisien regresi sebesar -0,098.Pengaruh negatif ini dikarenakan perusahaan kecil harus mengeluarkan biaya yang besar untuk pendanaan eksternal (Abdioglu, 2016). Oleh karena itu perusahaan kecil harus memiliki cash holding yang optimal sehingga bisa digunakan sebagai sumber pendanaan internal.

Hasil ini sesuai dengan hasil penelitian (Khalil dan Ali, 2015) dan (Abdioglu, 2016) yang menunjukkan bahwa ukuran perusahaan berpengaruh negatif terhadap cash holding. Namun berbeda dengan hasil penelitian (Zoubi, 2013) dan (Cheryta et al., 2017) yang menemukan bahwa ukuran perusahaan tidak berpengaruh terhadap cash holding.

\section{Pengaruh Ukuran Perusahaan terhadap hubungan antara Kepemilikan Institusional dengan Cash Holding}

Setelah masuknya variabel Ukuran Perusahaan sebagai variabel pemoderasi maka hubungan antara Kepemilikan Institusional dengan Cash Holding berubah menjadi positif. Dengan demikian dapat dikatakan bahwa Ukuran Perusahaan memperkuat pengaruh terhadap hubungan antara Kepemilikan Institusional dengan Cash Holding. Artinya, jika Ukuran Perusahaan meningkat maka 
dengan meningkatnya kepemilikan Institusional akan menaikkan Cash Holding. Hasil penelitian ini sejalan dengan penelitian Anjum dan Malik (2013), Ali et al (2016) dan Jamil et al (2016) yang menemukan hubungan positif antara ukuran perusahaan dengan cash holding. Sesuai dengan hipotesis yang telah dikemukakan, Ketika perusahaan berukuran besar, kepemilikan institusional tentu semakin besar pula yang menandakan akan semakin besar kekuatan suara dan dorongan dari institusi tersebut untuk mengawasi manajemen. Akibatnya, akan memberikan dorongan yang lebih besar untuk mengoptimalkan cash holding perusahaan. Kepemilikan institusional memiliki kemampuan untuk mengendalikan pihak manajemen melalui proses monitoring secara efektif sehingga mengurangi tindakan manajemen melakukan manajemen laba.

\section{Pengaruh Ukuran Perusahaan terhadap hubungan antara Profitabilitas dengan Cash Holding}

Setelah masuknya variabel Ukuran Perusahaan sebagai variabel pemoderasi maka hubungan antara Profitabilitas dengan Cash Holding berubah menjadi positif. Dengan demikian dapat dikatakan bahwa Ukuran Perusahaan memperkuat pengaruh terhadap hubungan antara Profitabilitas dengan Cash Holding. Artinya, jika Ukuran Perusahaan meningkat maka dengan dengan meningkatnya Profitabilitas akan menaikkan Cash Holding. Perusahaan yang memiliki ukuran yang lebih besar mempunyai pengaruh terhadap peningkatkan profitabilitas perusahaan (Hansen dan Juniarti, 2014). Sependapat dengan pernyataan tersebut, Niresh dan Velnampy (2014) mampu membuktikan bahwa ukuran perusahaan mempunyai pengaruh positif signifikan terhadap profitabilitas. Perusahaan yang berukuran lebih besar akan relatif stabil dan mampu menghasilkan profit. Profitabilitas yang tinggi menggambarkan bahwa perusahaan mengalami kenaikan dalam hal pendapatan sehingga menyebabkan ketersediaan kas (cash holding) juga semakin tinggi.

\section{KESIMPULAN DAN SARAN}

\section{Kesimpulan}

Berdasarkan hasil pengujian dan analisis yang telah dilakukan, maka dapat disimpulkan bahwa kepemilikan institusional, profitabilitas dan ukuran perusahaan berpengaruh negatif terhadap cash holding perusahaan terindeks LQ45 di Bursa Efek Indonesia, sedangkan Ukuran Perusahaan sebagai variabel moderasi memperkuat pengaruh terhadap hubungan antara kepemilikan institusional dan profitabilitas dengan cash holding.

\section{Saran}

Berdasarkan hasil penelitian, saran akademis dan saran praktis yang dapat diberikan adalah Penelitian selanjutnya diharapkan dapat memperluas subjek penelitian, tidak hanya pada perusahaan Indeks LQ45 saja karena memungkinkan ditemukannya hasil dan kesimpulan yang berbeda jika dilakukan pada subjek penelitian yang berbeda. Diharapkan pada penelitian selanjutnya dapat mengembangkan faktor-faktor lain yang dapat mempengaruhi cash holding berhubung variabel yang diteliti dalam penelitian ini hanya mampu menjelaskan 10,8\%, cash holding, sedangkan sisanya 89,2\% 
dijelaskan oleh variabel lain yang tidak dimasukkan dalam model penelitian ini, seperti: cash flow,

likuiditas, leverage, net working capital.

\section{REFERENSI}

Abdioglu, N. 2016. Managerial Ownership and Corporate Cash Holdings: Insights from an Emerging Market. Business and Economics Research Journal, Vol. 7 No.2. Hal: 29-41.

Al-Najjar, B., and Belghitar, Y. 2011. Corporate Cash Holdings and Dividend Payments: Evidence from Simultaneous Analysis. Managerial and Decision Economics, Vol. 3 No. 4. Hal: 231-241.

Ali, S., Ullah, M., and Ullah, N. 2016. Determinants of Corporate Cash Holdings: "A Case of Textile Sector in Pakistan.” International Journal of Economics \& Management Sciences, Vol. 5 No. 3. Hal: 1-10. https://doi.org/10.2139/ssrn.2728200

Alves, P., and Morais, F. 2018. Cash Holdings Are Increasing and Financial Crisis Strengths It. Munich Personal RePEc Archive, (83799). Retrieved from https://mpra.ub.unimuenchen.de/83799/

Anjum, Sara and Qaisar Ali Malik. 2013. Determinants of Corporate Liquidity: An Analysis of Cash Holdings. IOSR Journal of Business and Management. Vol. 7. Hal: 94-100.

Arfan, M., Basri, H., Handayani, R., Shabri, M., Fahlevi, H., and Dianah, A. 2017. Determinants of Cash Holding of Listed Manufacturing Companies in The Indonesian Stock Exchange. DLSU Business and Economics Review, Vol. 26 N0.2. Hal: 1-12.

Azinfar, K., and Shiraseb, Z. 2016. An Investigation into The Impact of Ownership Structure on The Level of Cash Holdings in The Companies Accepted in Tehran Stock Exchange Market. Marketing and Branding Research, Vol. 3. Hal: 194-205.

Cheryta, A. M., Moeljadi, and Indrawati, N. K. 2017. The Effect of Leverage, Profitability, Information Asymmetry, Firm Size on Cash Holding and Firm Value of Manufacturing Firms Listed at Indonesian Stock Exchange. International Journal of Research in Business Studies and Management, Vol. 4 No. 4. Hal: 21-31. https://doi.org/10.22259/ijrbsm.0404004

Im, H., Park, H., Pathan, S., and Yu, S. 2018. Institutional Ownership and The Value of Cash Holdings. In FMA Conference. Retrieved from http://www.apjfs.org/resource/global/cafm/2018-3-3.pdf

Jamil, S., Anwar, A., Afzaal, N., Tariq, A., dan Asif, M. 2016. Determinants of Corporate Cash Holdings : Empirical Analysis of Pakistani Firms. IOSR Journal of Business and Management, Vol. 7 No. 3. Hal: 29-35. https://doi.org/10.9790/5933-0703032935

Kafayat, A., Rehman, K. U., and Farooq, M. 2014. Factors Effecting Corporate Cash Holding of NonFinancial Firms in Pakistan. Acta Universitatis Danubius. Economica, Vol. 10 No.3. Hal: 3541. https://doi.org/10.1016/j.radmeas.2008.01.005

Khalil, S., and Ali, L. 2015. The Effect of Family Ownership on Cash Holdings of the Firm (Karachi Stock Exchange). International Journal of Academic Research in Business and Social Sciences, Vol. 5 No. 6. Hal: 133-141. https://doi.org/10.6007/ijarbss/v5-i6/1662

Khan, A., Bibi, M., and Tanveer, S. 2016. The Impact of Corporate Governance on Cash Holdings: A Comparative Study of The Manufacturing and Service Industry. Financial Studies, Vol. 20 No. 3. Hal: 40-79.

Kim, J., Kim, H., and Woods, D. 2011. International Journal of Hospitality Management Determinants of corporate Cash-Holding Levels: an Empirical Examination of The Restaurant Industry. International Journal of Hospitality Management, Vol. 30 No. 3. Hal: 568-574. https://doi.org/10.1016/j.ijhm.2010.10.004

Kotler. Philip dan Keller Kevin. 2011. Manajemen Pemasaran. Jilid 1, diterjemahkan oleh Benyamin Molan. Jakarta: PT. Indeks Kelompok Gramedia

Mawardi dan Nurhalis. 2018. Pengaruh Corporate Governance Terhadap Cash Holding Pada Perusahaan Manufaktur di Bursa Efek Indonesia. Jurnal Manajemen dan Inovasi, Vol. 9 No.1. Hal: 75-90.

Mohd, K. N. T., Latif, R. A., dan Saleh, I. 2015. Institutional Ownership and Cash Holding. Indiana Journal of Science and Technology, Vol. 8 (November). Hal: 1-6. https://doi.org/10.17485/ijst/2015/v8i32/92124

Opler, T., Pinkowitz, L., Stulz, R., and Williamson, R. 1999. The Determinants and Implications of 
Corporate Cash Holdings. Journal of Financial Economics, Vol. 5.

Sari, D. M., dan Ardian. 2019. Cash Holding , Cash Flow dan Profitability: Studi pada Perusahaan Manufaktur yang Terdaftar di Bursa Efek Indonesia. Jurnal Dinamika Akuntansi dan Bisnis, Vol. 6 No. 1. Hal: 29-38.

Senjaya, S. Y., dan Yadnyana, I. K. 2016. Analisis Pengaruh Investment Opportunity Set, Cash Conversion Cycle dan Corporate Governance Structure terhadap Cash Holdings. E-Jurnal Ekonomi Dan Bisnis Universitas Udayana, Vol. 5 No. 8. Hal: 2549-2578.

Silaen, R., dan Prasetiono. 2017. Analisis Faktor-Faktor yang Mempengaruhi Tingkat Cash Holding pada Bank Umum yang Terdaftar di Bursa Efek Indonesia Tahun 2011-2015. Diponegoro Journal of Management, Vol. 6 No. 3. Hal: 1-11.

Sofyaningsih, S., dan Hardiningsih, P. 2011. Struktur Kepemilikan, Kebijakan Dividen, Kebijakan Utang dan Nilai Perusahaan. Dinamika Keuangan Dan Perbankan, Vol. 3 No. 1. Hal: 68-87.

Souissi, M., and H. Khlif. 2012. Meta Analytic Review of Disclosure Level and Cost of Equity Capital. International Journal of Accounting and Information Management. Vol. 20 No. 1. Hal: 49-62.

Yanti, Susanto, L., Wirianata, H., and Viriany. 2019. Corporate Governance, Capital Expenditure dan Cash Holdings. Jurnal Ekonomi, Vol. XXIX No. 01. Hal: 1-14.

Zoubi, T. Al. 2013. Corporate Cash-Holding Decisions: Amman Stock Exchange. Brunel University. 